\title{
Hazard Zoning for Landslides Connected to Torrential Floods in the Jerte Valley (Spain) by using GIS Techniques
}

\author{
R.M. CARRASC ${ }^{1, \star}$, J. PEDRAZA ${ }^{2}$, J.F. MARTIN-DUQUE ${ }^{2}$, M. MATTERA ${ }^{2}$, \\ M.A. SANZ ${ }^{2}$ and J.M. BODOQUE 2 \\ ${ }^{1}$ Departament• de Ingeniería Geológica y Minera, Facultad de Ciencias del Medi॰ Ambiente, \\ Universidad de Castilla-La Mancha, Campus Fabrica de Armas, 45071 Toledo, Spain;

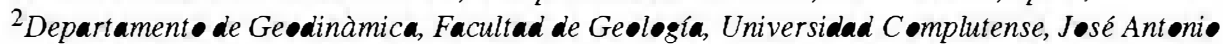 \\ Novais $s / n, 28040$ Madrid, Spain
}

\begin{abstract}
The Jerte Valley is a northeast-southwest tending graben located in the mountainous region of west central Spain (Spanish Central System). Mass movements have been a predominant shaping process on the Valley slopes during the Quaternary. Present day activity is characterized as either 'first-time failure' (shallow debris slides and debris flows) or 'reactivations' of pre-existing landslides deposits.

A delineation of landslide hazard zoning within the Valley has been carried out by using the detailed documentation of a particular event (a debris slide and a sequel torrential flood, which occurred on the Jubaguerra stream gorge), and GIS techniques. The procedure has had four stages, which are: (1) the elaboration of a susceptibility map (spatial prediction) of landslides; (2) the elaboration of a map of 'restricted susceptibility' in the particular case of slopes that are connected to streams and torrents (gorges); (3) the elaboration of a digital model which relates the altitude to the occurrence probability of those particular precipitation conditions which characterized the Jubaguerra event and (4) the combination of the probability model with the 'restricted susceptibility map', to establish 'critical zones' or areas which are more prone to the occurrence of phenomena that have same typology as this one.
\end{abstract}

Key words: Spanish Central System, debris slide, debris flow, torrential flood, digital precipitation models, Geographic Information Systems.

\section{Introduction}

The most important landslide deposits in the slopes of the Spanish Central System have been considered as relict from the colder phases of the Pleistocene and the beginning of the Holocene (Butzer and Fränzle, 1959; IГGE, 1989).

^ Author for correspondence: Departamento de Ingeniería Geológica y Minería, Facultad de Ciencias del Medio Ambiente, Universidad de Castilla-La Mancha, Campus Fábrica de Annas, 45071 Toledo, Spain; E-mail: rosa.carrasco@uclm.es 


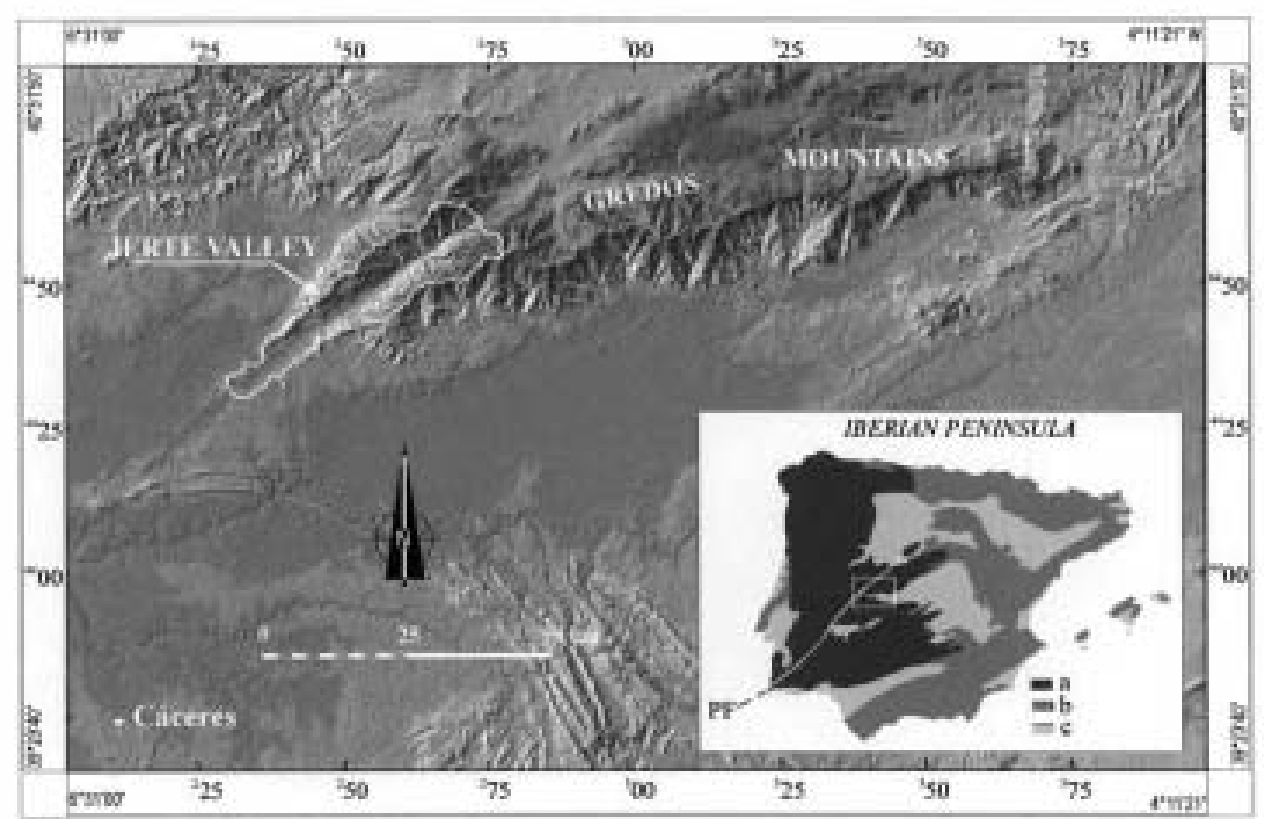

Figure 1. Location of the Jerte Valley in the Iberian Peninsula: (a) Hesperian or Hercynian Massif; (b) Alpine mountainous systems; (c) Tertiary basins; PF) Odenira-Plasencia fault.

However, taking new data int consideration, it has been pøssible to question

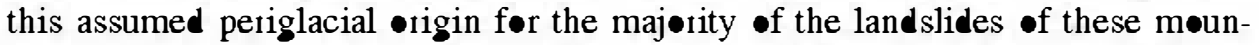
tains. This has been deduced from the present activity of debris flows (Palacios

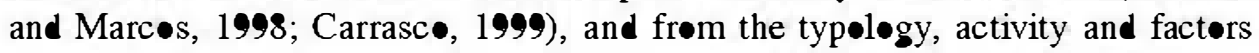
invelved in the •rigin $\bullet$ the landslides of the Jerte Valley (Carrasc $\bullet$ and Pedraza, 1992).

This w॰rk is based $\bullet$ the latter, the Jerte Valley. Its main $\bullet$ bjective is to carry

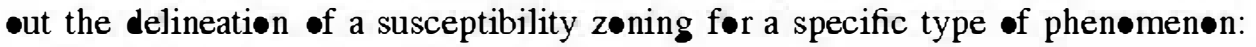
landslides cønnected tø tørrential activity.

\section{Physical Setting of the Jerte Valley}

The Jerte Valley is a n॰rtheast tending tectonic intra-mountainøus depression (•r complex graben), which covers an area of $438 \mathrm{~km}^{2}$. It is located in the Spanish Central System, an intra-plate mountainous range within the Iberian Hetcynian Massif (Figure 1).

The main stage in the develøpment of the Jerte Valley graben to॰k place between the Late Pliocene and Early Pleistocene; the downthrown blocks ate bordered by a fault set in NE-SW direction (Odemira-Plasencia fault, Figure 1). This graben was develøped within the Miocene uplifted range; these fault-blocks mountains are bordeted by NW-SE and NNW-SSE fault systems. 
The floor of the Valley has a stair-step morphology due to cross faulting of the graben so that it is approximately $1,000 \mathrm{~m}$.a.s.l., at the eastern end, but only about 360 m.a.s.l. in the west. The Valley sides also diminish as one goes from east to west, due to the lowering of the mountain heights. In the eastern side of the Valley, the mountain heights are 2,200 m.a.s.l., and slopes average 1,200 m; whereas in the west side of the Valley, they are only at an elevation of 650 m.a.s.l., so the slopes average only $360 \mathrm{~m}$ in length. These slopes show frequent fault line scarps separating small benches which lay at different levels, as well as incised V-shaped gorges.

The predominant geological materials in the Valley are biotitic granites (of Carbonif erous age), which show chemical weathering zones (Molina et al., 1990). There are also several groups of surficial deposits (of Quaternary age), which are: (1) fluviotorrential sediments; (2) tills and periglacial soils; and (3) mass movement deposits.

The climate in this Valley is the mountainous variant of the Mediterranean, with a marked seasonal contrast; it has a cool and niveopluvial pattern in the Eastern area, and a temperate and pluvial one throughout the West. The remains of natural vegetation are arranged according to the following altitudinal succession: holm oak forests (up to 1,000 m.a.s.l., exceptionally up to 1,200 m.a.s.l.), oak forest (from $1,000-1,100$ to 1,800 m.a.s.l.), Cytisus shrublands (ranging from 1,800 to 2,100 m.a.s.l.) and alpine pastures (above 2,100 m.a.s.l.).

Although these characteristics are not very frequent over the Spanish Central System, neither are they exceptional. Thus, similar to the Jerte Valley are the El Paular, Tiétar and Alberche Valleys: in fact, recently initiated investigations within these areas, have observed similar debris flow activity and ancient slides.

\section{The Mass Movements in the Jerte Valley and their Hazardousness}

Landslides occupy $23 \%$ of the total surface area of the Jerte Valley and 830 individual landslides have been identified. According to the classification by Varnes (1978), these landslides have the following typologies: rock and debris fall (36\% of the total), different types of slides ( $56 \%$ of the total) and mud and debris flows ( $8 \%$ of the total).

Spatial relationships of these landslides were determined through the statistical analysis of the Brunsden's parameters, following a similar method already used by Hansen (1984) and Irigaray and Chacón (1991). Their chronology was established from morphological and stratigraphic relationships.

Taking this data into account, the landslides of the Jerte Valley can be grouped in three sequences or generations (Carrasco, 1999).

The first generation includes the landslides that occurred (paroxysmal phase) during the main phase of the forming of graben: from Late Pliocene to the Middle Pleistocene. They are of either single or multiple styles, have deep ruptures, and mainly displace saprolite. The average area of the displaced material is $0.3 \mathrm{~km}^{2}$, 
but they can reach $3 \mathrm{~km}^{2}$. Their spatial discibution does not appear to be random: there is a strong and direct correlation between the total area of the terrain affected by these landslides and the proximity of fault scarps. As it has been pointed out (Alexander and Formichi, 1993; Crozier et al., 1995), these data indicate that the seismic activity is one of the triggering factors of this type of landslides.

The second generation consists of the landslides which occurred (paroxysmal phase) during the main gorge forming phase caused by glacial, periglacial and pluvial stages: from Middle Pleistocene up to late Holocene. They are either falls, single debris slides, debris flows, or mud flows. Slides and flows have shallow ruptures, and the main displaced material is regolith. Their size average is 0.02 $\mathrm{km}^{2}$, but they can reach up to $0.1 \mathrm{~km}^{2}$. Slides and flows show a preferential location in gorge slopes, while rock falls occur in rocky cliffs. However, there are also other morphological elements with which they show a good correlation, such as the presence of regolith, aspect and slope gradient. According to this, they have a more random distribution than the first generation.

The third generation groups the landslides that occurred (paroxysmal phase) during the period of anthropogenic activity in the Valley: from the Bronze Age (3000 BP) to the present (during the late Holocene). With regard to mass movements, this interval is frequently divided in three periods: early historical, recent historical, and present-day (Flageollet, 1989). These landslides are similar to those described for the second generation, with the same typologies but of smaller size $\left(0.006 \mathrm{~km}^{2}\right.$ as average area). However for the third generation landslides, as opposed to the other two generations, anthropogenic activity is a factor that needs to be considered in order to explain the origin of these mass movements.

The landslides of first and second generation took place under different conditions from present-day. Some of those landslides do not show signs of activity; therefore, they should be classified as 'inactive relict', in the terminology of the WP/WLI, 1993. Nevertheless, signs of current activity (cracks, ree trunks curvature, fence ruptures, minor slides, etc.) have been observed in a few of these deposits (mainly in the displaced materials of first generation landslides); for that reason, according to the WP/WLI classification they should be referred to as 'dormant'. These signs coincide with areas that have been modified by human activity. Characteristic examples of these reactivations are (Figure 2): in the single debris slide of Tornavacas, an area where cherry rees are cultivated in terraces; and in the multiple debris slide of El Rebollar, where land ransformation has barely taken place; in fact, the original forest remains in these areas.

The involvement of anthropogenic activity as a landslide reactivation factor, and the hazard conditions it causes (some villages are located on these deposits; Figure 3 ), were the aims of a previous study (Carrasco et al., 2000).

The current activity of third generation landslides is low. With the available data, only four cases have been recorded in the last 20 years, one of them was well documented. The event, a debris slide (Figure 4 A), took place on 24 January 1996, early in the morning, on the right slope of the Arroyo de Jubaguerra gorge 


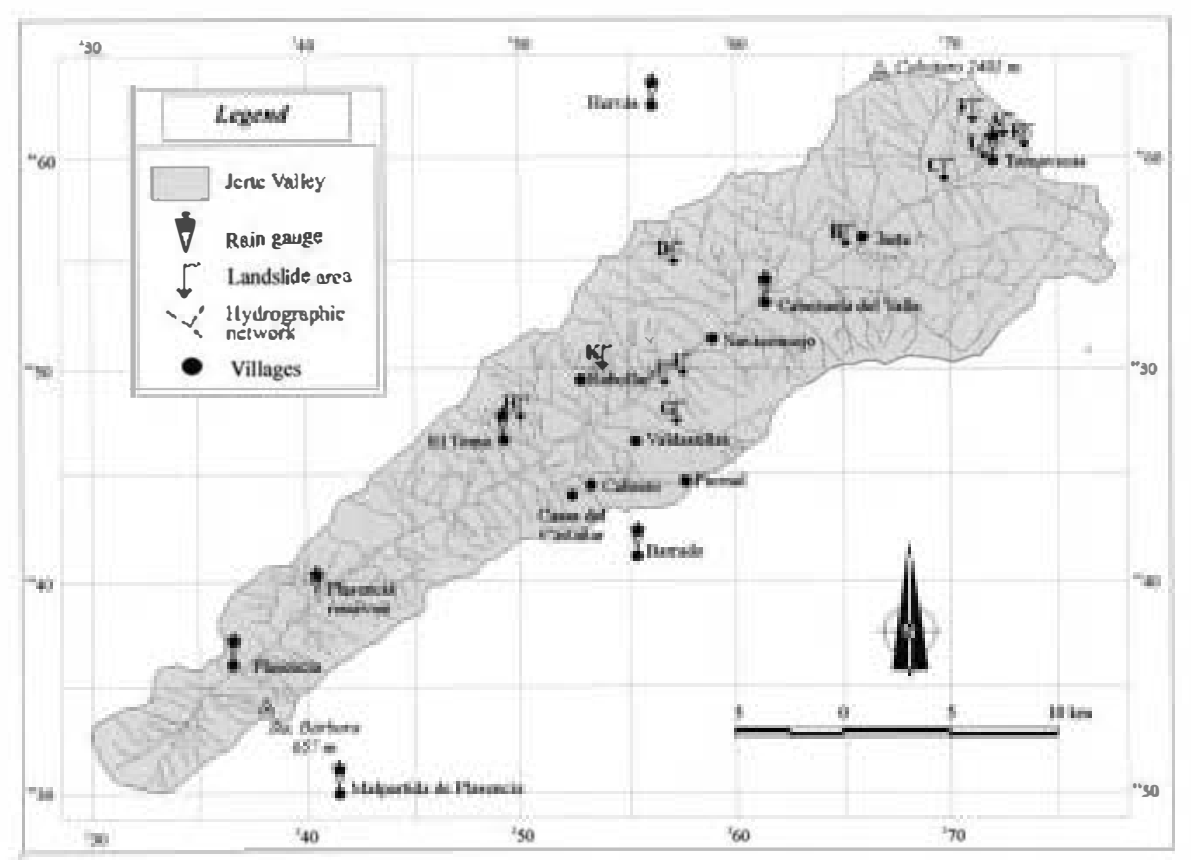

Figure 2 Location of landslides activity in the Jerte Valley occurred the last 20 years (is marked with capital letters; from A to L). Their time of occurrence are: February 1986 (A, B); December 1994 (C, D); December 1995 (E, F); January 1996 (G, H); March 1996 (I); 6, December 1996 (J, K); January 2001 (L). A, E, G and J, are first-time failures; the rest correspond to reactivations, and the date indicates a higher activity (increasing of the creep movement, falls, minor slides, etc.). G is the Jubaguerra debris slide, Ki s the El Rebollar slide, and $\mathrm{L}$ is the Tomavacas slide. The figure also shows the location of the rain gauges used for the precipitation analysis. Records were obtained from the Spanish National Meteorological Institute. Four rain gauges had a common record of last 15 years, another three the last 30 years, and one of them (Plasencia), recorded from 1919.

(Figure 2). The displaced material was approximately 18,000 cubic meters and most of it invaded the torrent channel damming the stream, which was at banlfull discharge. There are still accumulations plastered on both side slopes. The breaking -f the natural dam generated a flood wave, which reached up to the mouth of the watershed, $2.5 \mathrm{~km}$ downstream. Aløng the flood path, there were three stretches of

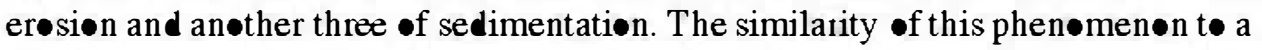
channelled debris flow is clear (see, før instance, Piersøn and Costa, 1987; C॰r॰m-

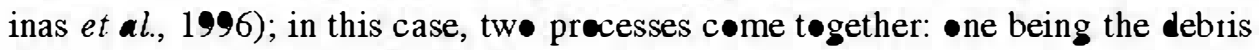
slide, triggeted by rainfall with the possible contribution of bank undercutting; the -ther being the exceptional fløed.

Our motives for having analysed these phenomena regarding their hazard were the effects of this flood (Figure 4B), and the fact that søme torrents similar to the Jubaguerra cross several villages in the Valley. 


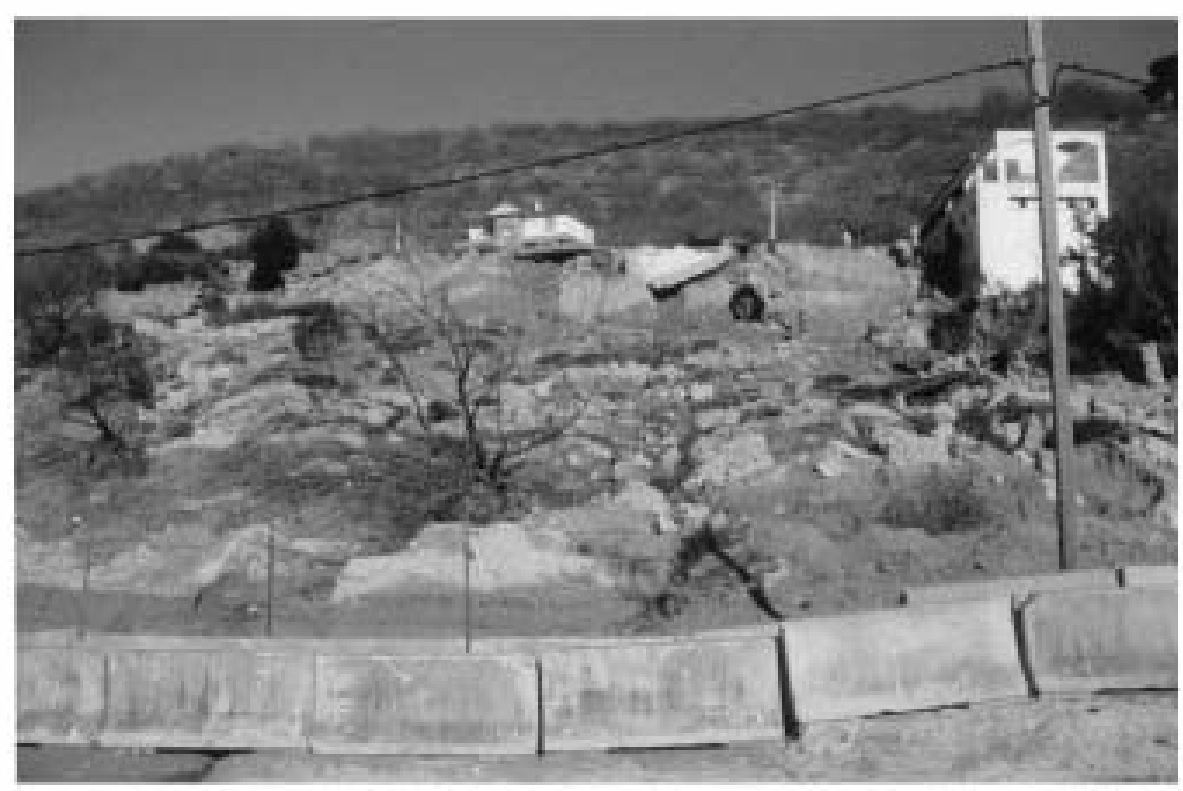

Figure 3 Minor slide which took place on 17 January 2001, in Tomavacas village; the displaced material is from deposits of a previous debris slide (first generation).

\section{Characterization of Slope Instability Factors}

Sløpe instability factors have been widely described in literature (see, før instance, Varnes, 1978; Giani, 1992; Carrara et al., 1995). For the Jerte Valley, both determining and triggeting factors wete characterized by studying all the mass movements and controlling and measuring present-day activity.

Determining factors, tesponsible for the spatial distribution of the third generation mass movements, are:

Unconsolidated materials. They cønsist in saprølite, regølith, and surficial dep॰sits. Saprolite is a 'gnus mantle' with jllitic and kaølinitic clay material, which

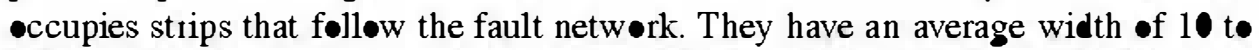

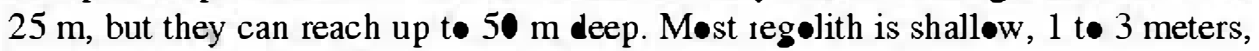
but it is extensively widespread on sløpes.

Gradient slope and aspect. Due to the recent tectønic formation of the Valley, møst sløpes are steep. Fault scarps sløpes face NW and SE. Streams tributary to the Jerte

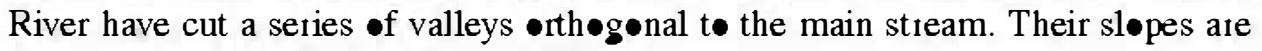
als• steep and mostly face NE and SW.

Vegetation/and use. Human activity has been a cøntinuous process since early his-

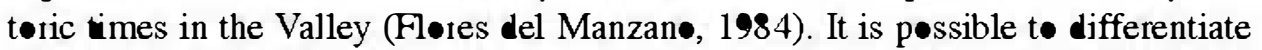
the following land use classes: (1) human settlements and their surroundings (this 


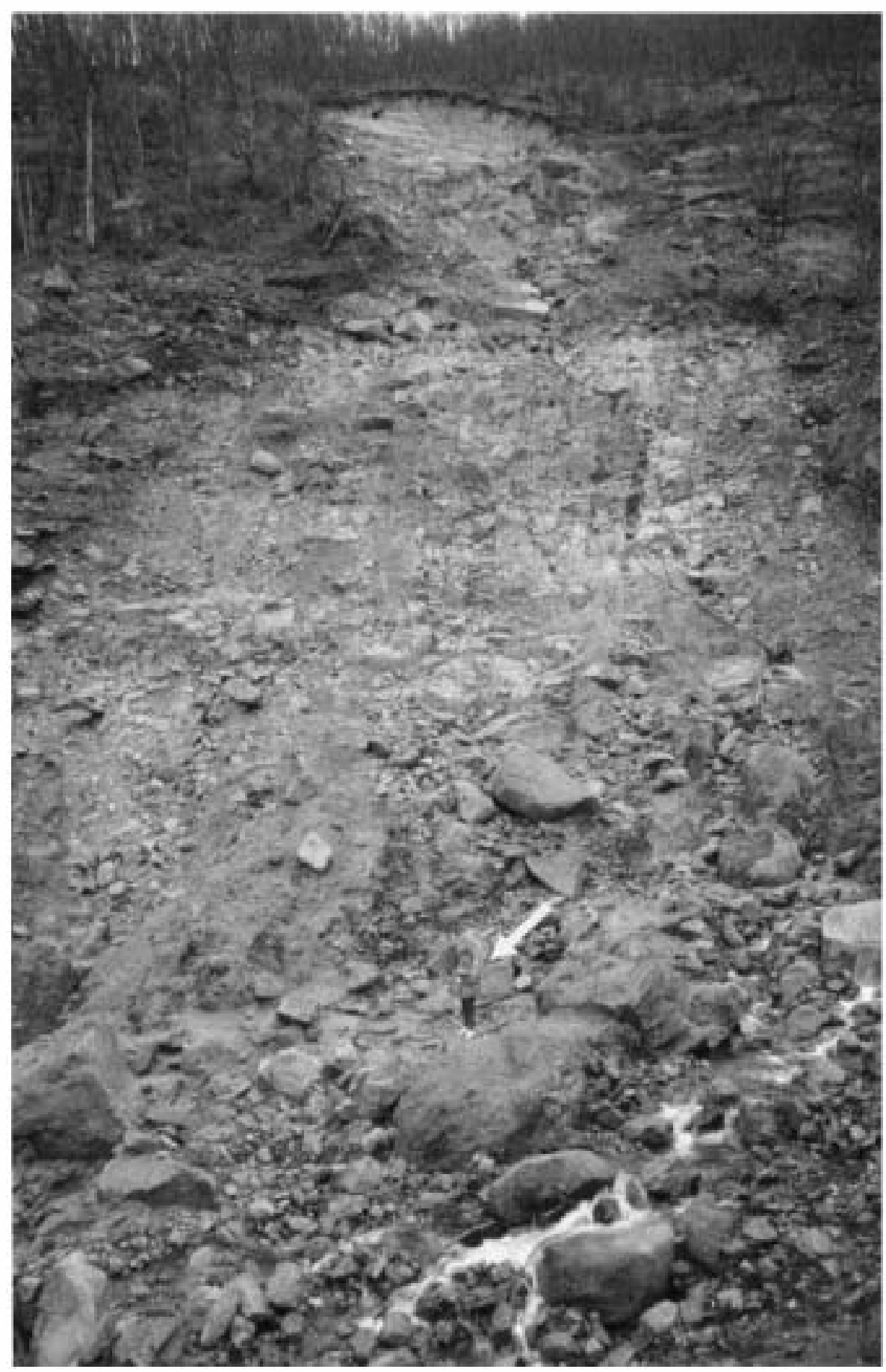

Figure 4. (A) Surface ruptrre of the Jubaguerra debris slide, displacing regolith materials (to see the scale, note the person pointed by an arrow). (B) The first sequence of debris flood deposit along the Jubaguerra stream. It took place after the first sequence of riverbank erosion and just beyond the first small waterfoll (it can be seen on the right upper corner of the figure). 
process began in the Bronze Age, $3000 \mathrm{BP}$ ); (2) prairies, scrubland and famed forests (the maximum deforestation occurred between the 13th and 17th century, for extensive grazing activities); (3) chesmut and vineyards (these activities were initiated in the Roman period, approximately in the 3rd-4th C BC); (4) olive wee orchards (initiated in the Muslim period, approximately in the 9th century); and (5) cherry cultivation (these orchards began to grow in the 19th century and massively expanded during the last 40 years). This latter process is important for the slope stability considering that evapotranspiration decreases noticeably in the orchards for two reasons: the roots' structure of cherry ree is shallower than the holm oak, oak, and chestnut forests, and besides the tree density is lower in orchards than in forest areas.

Rainfall is the main triggering factor for third generation landslides in the Valley (Carrasco et $\boldsymbol{a l}$., 2000) and it has a direct and indirect effect in this area: increasing pore water pressures in soils has a direct effect, thus decreasing their stability; increasing channel discharge has an indirect effect on the area as it leads to the undercutting of stream banks. In the former case (see, for instance, Garland and Olivier, 1993), the efficiency of the precipitation as a riggering factor is directly related to its continuity. The latter case occurs during floods in the gorges; these discharges can be caused by several situations: (1) rapid snow melting coinciding with rain episodes; (2) the cumulative effect of long precipitation periods; (3) high intensity and short-lasting rain.

Finally, it should be noted that despite the tectonic origin of the Valley and neotectonic signs in the Pleistocene fluvial terraces (such as faults, signs of bending by subsidence, and the bending of deposit borders), the Valley is classified as of very low seismicity; according to data of the Spanish National Geographical Institute, General Catalogue of Earthquakes (IGN, 2000), the maximum intensity experienced in this area is V on the European Macroseismic Scale (EMS).

\section{Methodology}

The first step was the characterisation of spatial probability, or susceptibility zones (Brabb, 1984). The starting point in carrying out this work was a GIS based model to analyse the susceptibility zoning for the reactivation of previous landslides in the Valley (Carrasco et al., 2000). This method was based on the calculation of the landslides density for each class of each factor. This index is similar to the Landslide Susceptibility Index (LSI) used by Sarkar et al. (1995), and to Surface Percentage Index (SPI) by Uromeihy and Mahdavif ar (2000). From this first approach, the procedure that is presented in this work is applied to estimate the susceptibility for future landslides (third generation typologies), and incorporates the Bayes conditioning probability.

The second step was to add a restrictive condition to the susceptibility map. The objective of this condition was the delineation of those areas in which the landslides and the torrential flows could be connected. These are areas where stream under- 
cutting can occur contributing to the triggering process, and where the displaced material can reach the channels to generate either a channelled debris flow or a torrential flood. This condition was generated by the application of a 'morphological pattern' search from the Digital Elevation Model, or 'neighbourhood analysis' (Van Westen, 1993).

Finally, by using the 'precipitation conditions' that characterized the Jubaguerra and El Rebollar events, an analysis of the recurrence probabilities is done. This analysis is used in order to make a first approximation of the 'time probability' of the triggering factor.

\section{Data Acquisition and Storage using GIS}

Most of the spatial information needed to develop the methodology came from existing documentation. These thematic maps were initially stored in a digitalvector format, and later ransformed into a raster format - with a pixel size of 25 $\times 25 \mathrm{~m}$, for the analysis.

The landslides that were used for this analysis are those of the third generation. This map was produced combining aerial photo-interpretation, fieldwork and historical records (Carrasco, 1999). The photo-interpretation was carried out using photos of flights of the years 1956 (at $1: 33,000$ scale) and 1985 (at $1: 18,000$ scale).

A lithologic map was produced from: (1) the geologic cartography at 1:50,000 scale, published by the Spanish Geological Survey; (2) a surficial deposits map, prepared from an aerial photo interpretation using the flights mentioned above and field checking; (3) a map of weathered materials, obtained by implementing GIS buffer analysis based on width weathering field measurements of the fault network. This resulted in a map of 11 lithologic units with distinct geo-mechanical and hydro-geological properties.

A digital vegetation/land use map was obtained from the vegetation cartography at $1: 50,000$ scale, published by the Spanish Environmental Deparment (edition of 1990).

On digitising 10-meter height spacing contours of existing $1: 25,000$ topographic maps, the 25-meter Digital Elevation Model (DEM) was constructed by using an interpolation model of Kriging. The derived maps of slope gradient and aspect were obtained from the DEM. A map of the hydrographical network was also constructed by digitising their representation on $1: 25,000$ topographic maps.

Precipitation data came from 8 rain gauges located along the Jerte Valley and its surroundings (Figure 2), and from another rain gauge within the region (Cáceres, with data from 1907; see Figure 1). Due to the fact that there are no pluviographs for any of the rain gauges analysed, the 24-hour total precipitation amount is the shortest interval for which data was available. 


\section{Data Analysis}

\subsection{GIS ANALYSIS (LANDSLIDE SUSCEPTIB ILITY MAP)}

A probabilistic method, following a 'pixel based calculation' approach (Van Westen, 1993), was followed. More specifically, the Bayes conditioning probability was used.

This analysis establishes for each pixel, the joint probability that a landslide would occur for each class of each factor (the same meaning as a susceptibility index, or density) and given the probability that this pixel is located within the given class. Mathematically it is:

$$
P(A)=\sum_{i=1}^{n}\left[P\left(A / B_{i}\right)\right] P\left(B_{i}\right),
$$

where $P(A)$ is the probability that a given pixel will develop a new landslide; $P\left(A / B_{i}\right)$ is the probability that a landslide has occurred for each class of each factor; and $P\left(B_{i}\right)$ is the probability of occurrence for each class of each factor.

Once the conditional probabilities were calculated outside the GIS (Table I), the final susceptibility map (Figure 5a) was constructed by assigning these probabilities to each factor map, and then by adding the corresponding conditional probabilities for each pixel.

\subsection{CONNECTION WITH TORRENTIAL CHANNELS CONDITION}

The application was based on a 'morphological pattern' search from the Digital Elevation Model (DEM). The procedure, specifically developed for this work, begins with a morphological analysis of the DEM; by comparing the altitude of each pixel with their neighbours, the program assigns its morphology to its pixel (such as summit, pass, mountain heights, concave or convex slopes, etc.). Then, a specific gorge-type-valley search analysis was carried out for gorge bottoms no wider than $25 \mathrm{~m}$ ( 1 pixel). This analysis is done by crossing typologies between the pattern and the morphological basis, applying a 180 degrees rotation in the vicinity of each point (due to the lineal polarity of the searched morphology). As a result, a Boolean image of gorge morphologies was obtained. By overlaying the susceptibility map (Figure 5a) and the gorges map, a landslide susceptibility map in gorge slopes is obtained (Figure 5b).

\subsection{TRIGGERING FACTOR: PRECIPITATION ANALYSIS}

According to Vames et al. (1984) a rigorous hazard zoning would involve combining the spatial prediction (spatial probability) with the time prediction (time probability). However, it has been recognised in several studies (Corominas, 1988; Ayala, 1995; Carrara et al., 1995) that the time prediction for the precise location of new landslides is difficult to establish. 
Table I. Values of conditioning probability for each class of each determining factor. $(B i) L A$, means area of $B i$ affected by landslides; see formula 1 for the meaning of the rest of the terms. Interval classes for gradient slope and aspect were obtained from mean and standard deviation of these values within the Valley.

\begin{tabular}{|c|c|c|c|c|c|}
\hline & E. Area & $\left(\mathbb{R}_{1}\right) L A$ & $P\left(A / B_{1}\right)$ & $P\left(B_{1}\right)$ & $P(A)$ \\
\hline \multicolumn{6}{|l|}{ Lithology class } \\
\hline Granites & 412542 & 2997 & $\mathbf{0 . 0 0 7 2 6}$ & 0.60043 & 0.00436 \\
\hline Grauwacque & 36788 & - & 0.00000 & 0.05354 & 0.00000 \\
\hline Schist & 10433 & - & 0.00000 & $\mathbf{0 . 0 1 5 1 8}$ & 0.00000 \\
\hline Diabase & 275 & - & 0.00000 & 0.00040 & 0.00000 \\
\hline Migmatite & 6798 & - & 0.00000 & 0.00989 & 0.00000 \\
\hline Gravel, sand and silt & 30542 & 589 & 0.01928 & 0.04445 & 0.00086 \\
\hline Sandst•ne and siltstøne & 2284 & - & 0.00000 & $\mathbf{0 . 0 0 3 3 2}$ & 0.00000 \\
\hline Cobbles, pebbles & 56674 & 159 & $\mathbf{0 . 0 0 2 8 1}$ & 0.08248 & 0.00023 \\
\hline Debris & 91435 & 7319 & 0.08005 & 0.13308 & 0.01065 \\
\hline Mud & 11546 & 175 & 0.01516 & 0.0168 & 0.00025 \\
\hline Sapr lite & 27766 & 244 & 0.0087 & 0.04041 & 0.00036 \\
\hline \multicolumn{6}{|l|}{ VegerLand use class } \\
\hline Orchard and pastureland & 58434 & 373 & 0.00638 & $\mathbf{0 . 0 8 5 1 4}$ & 0.00054 \\
\hline $\mathrm{H} \bullet \mathrm{lm} \bullet$ ak f $\bullet$ rest & 150244 & 3199 & 0.02129 & 0.21891 & 0.00466 \\
\hline Mountain prairies & 25273 & 70 & 0.00277 & 0.03682 & 0.00010 \\
\hline Scrubland & 24218 & 3131 & 0.01293 & 0.35286 & 0.00456 \\
\hline Unproductive & 20236 & 40 & 0.00198 & $\mathbf{0 . 0 2 9 4 8}$ & 0.00006 \\
\hline Farmed forest & 34138 & $\bullet$ & 0.00000 & $\mathbf{0 . 0 4 9 7 4}$ & 0.00000 \\
\hline Riparian førest & 10831 & 92 & 0.00849 & 0.01578 & 0.00013 \\
\hline Olive tree cultivation & 26266 & 638 & 0.0242 & 0.03827 & 0.00093 \\
\hline Cherry tree cultivation & 78796 & 3103 & 0.03938 & 0.11481 & 0.00452 \\
\hline Fruit tree cultivation & 13883 & 722 & 0.05201 & 0.02023 & 0.00105 \\
\hline Crøp cultivation & 7255 & - & 0.00000 & 0.01057 & 0.00000 \\
\hline Chestnut-hølm •ak & 11501 & 115 & 0.01000 & 0.01676 & 0.00017 \\
\hline Pine reførestatiøn & 7288 & $\bullet$ & 0.00000 & 0.01062 & 0.00000 \\
\hline \multicolumn{6}{|l|}{ Gradient class } \\
\hline - $-6^{\bullet}$ & 141609 & 776 & $\mathbf{0 . 0 0 5 4 8}$ & $\bullet .20633$ & 0.00113 \\
\hline $6-12^{\bullet}$ & 147921 & 2859 & 0.01933 & 0.21553 & 0.00417 \\
\hline $12-18^{\bullet}$ & 184309 & 3347 & $\bullet .01816$ & 0.26854 & 0.00488 \\
\hline $18-24^{\bullet}$ & $16 \bullet 688$ & 3636 & 0.02263 & 0.23413 & 0.00530 \\
\hline $24-30^{\bullet}$ & 49087 & 845 & 0.01721 & 0.07152 & 0.00123 \\
\hline$>30^{\circ}$ & 2677 & 20 & $\mathbf{0 . 0 0 7 4 7}$ & 0.00390 & 0.00003 \\
\hline \multicolumn{6}{|l|}{ Aspect class } \\
\hline $349.5-5.5$ & 33102 & 218 & 0.00659 & 0.05212 & 0.00034 \\
\hline $5.5-50$ & 33834 & 182 & 0.00538 & 0.05327 & 0.00029 \\
\hline $50-94.5$ & 27932 & 163 & 0.00584 & 0.04398 & 0.00026 \\
\hline $94.5-119$ & 33115 & 587 & 0.01773 & 0.05214 & 0.00092 \\
\hline $119-143.5$ & 76605 & 1700 & 0.02219 & 0.12062 & 0.00268 \\
\hline $143.5-168$ & 108073 & 3607 & •.03338 & 0.17016 & 0.00568 \\
\hline $168-192.5$ & 65291 & 1541 & 0.02360 & 0.10280 & 0.00243 \\
\hline $192.5-217$ & 33506 & 541 & 0.01615 & 0.05276 & 0.00085 \\
\hline $217-251$ & 36362 & 167 & 0.00459 & 0.05725 & 0.00026 \\
\hline $251-285.5$ & 47244 & 119 & 0.00252 & 0.07439 & 0.00019 \\
\hline $285.5-301.5$ & 34085 & 214 & 0.00628 & 0.05367 & 0.00034 \\
\hline $301.5-317.5$ & 47457 & 686 & 0.01446 & 0.07472 & 0.00108 \\
\hline $317.5-333.5$ & 58510 & 1014 & •.01733 & 0.09212 & 0.00160 \\
\hline $333.5-349.5$ & 51228 & 744 & $\bullet .01452$ & 0.08066 & 0.00117 \\
\hline
\end{tabular}



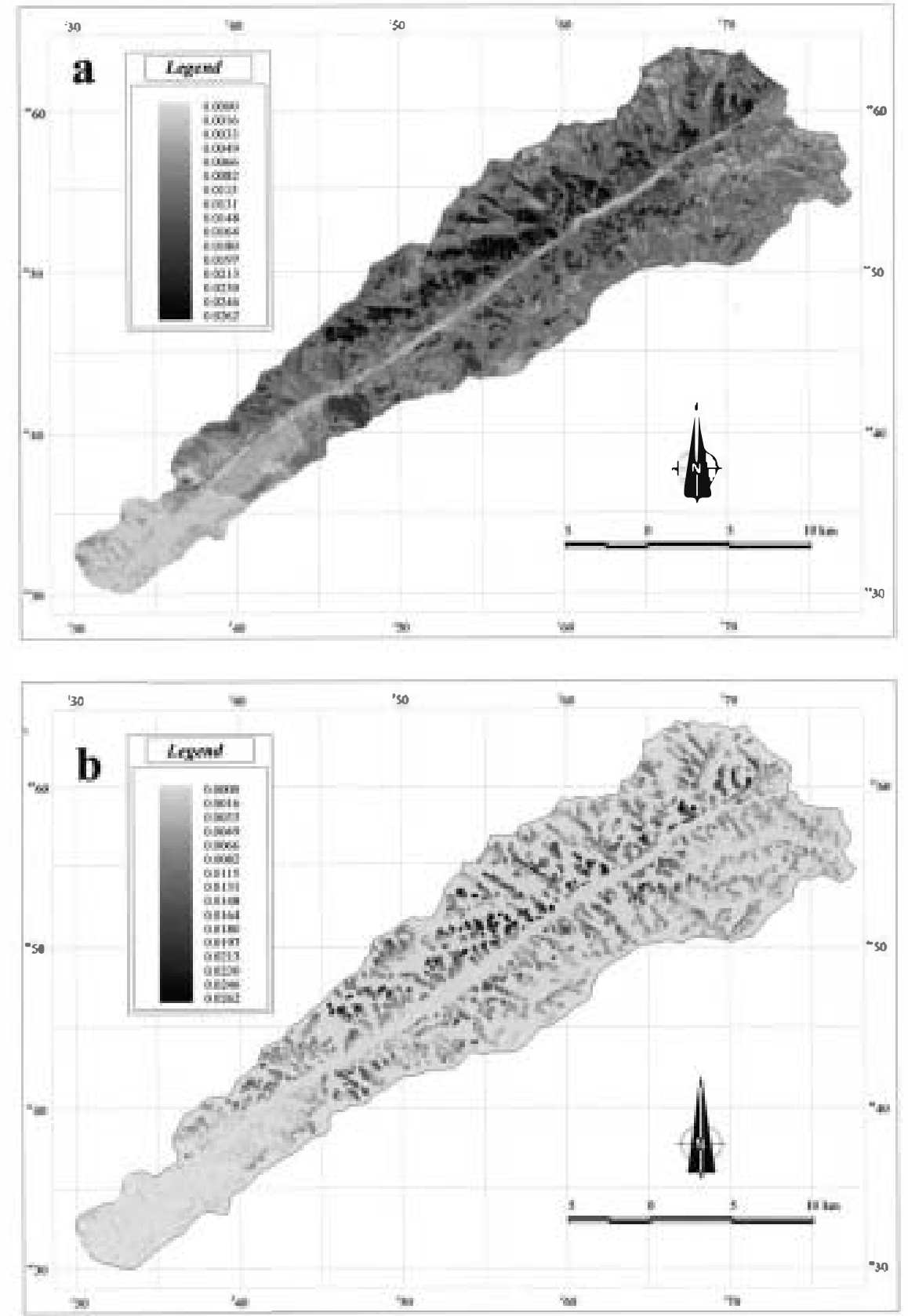

Figure 5 (a) Landslides susceptibility map (it was constructed by using a conditioning probability approach. (b) Landslides susoeptibility in gorge slopes or 'restricted susceptibility map'. 
As for the Jerte Valley, due to the lack of data available (that is, 12 landslides for the last 20 years and precipitation data only in $\mathrm{mm} /$ day), neither a landslide frequency analysis (Van Westen, 1993) nor Caine's threshold relationships (Corominas et al., 1996) could be established. Given these limitations, another alternative has been carried out in this work in order to relate precipitations events to mass movement activity. Essentially, the aim is to establish a first approximation of the time probability of this activity. The procedure is based on the calculation of the recurrence intervals of the precipitation conditions associated with two well-documented landslides, which, in their fundamental characteristics, can be considered to represent the types of present-day mass movements in this area. These are (see Chapter 3 and Figure 2): 'first-time failures' in gorge slopes (Jubaguerra type) and 'reactivation of dormant landslides' (Rebollar type).

The analysis consists of calculating the recurrence interval of the $24 \mathrm{~h}$, monthly, and cumulative autumn-winter precipitation that preceded those phenomena.

The procedure had the following steps:

(A) establishing the mathematical function(s), which correlate precipitation amount and altitude (Figure 6). One of the eight rain gauges of the Valley was rejected for this analysis (Hervás), due to the lack of coherence of its data;

(B) from these mathematical functions, shown in Figure 6, a new mathematical expression (2) has been obtained; this expression allows the calculation of 'longer precipitation series' concerning the Valley, in correlation to the more complete record outside the Valley (Cáceres), as well as the establishment of the precipitation values at any location within the Valley;

$$
P_{V}=\frac{\sum_{i=1}^{n} \boldsymbol{a}\left(H_{V}-H_{S i}\right)+P_{S i}}{n},
$$

where $P_{V}$ is the average precipitation at a desired location; $H_{V}$ is the average altitude of the Valley $(866.6 \mathrm{~m}) ; H_{S i}$ is the altitude of the desired locations; $a$ is the intersection value (constant value, that depends on the quantity of precipitation); $P_{S i}$ is the precipitation value used to calculate the series; and $n$ is the number of rain gauges.

(C) from these 'longer precipitation series', calculate the recurrence intervals and the probabilities of precipitation conditions for the two classes of current landslides activity (Tables II and III). Such calculation was made following the standardized method: the corresponding precipitation data (24-h, monthly and cumulative autumn-winter precipitation) for each location (Jubaguerra and El Rebollar) were ranked according to their magnitude, with the greatest value being ranked highest. From these series, the recurrence intervals were determined by:

$$
\text { Recurrence interval }=\frac{\text { Number of years of record }+1}{\text { Rank of the individual precipitation datum }} .
$$


Table II. Precipitation data associated with: (a) El Rebollar (reactivation landslide type); (b) Jubaguerra (first time failure type).

\begin{tabular}{|c|c|c|c|c|c|c|c|}
\hline \multirow[t]{2}{*}{$\begin{array}{l}\text { Løcation and } \\
\text { altitude }\end{array}$} & \multirow[t]{2}{*}{$\begin{array}{l}\text { Max. } 24 \mathrm{~h} \\
\text { precipitatiøn }\end{array}$} & \multicolumn{4}{|c|}{$\begin{array}{l}\text { Priør precipitation hist } \bullet r y \text { frøm the } \\
\text { beginning } \bullet \text { the hy r } \bullet \text { gic al year }\end{array}$} & \multirow{2}{*}{$\begin{array}{l}\text { Mønthly } \\
\text { precip. } \\
\text { Dec }\end{array}$} & \multirow[t]{2}{*}{$\begin{array}{l}\text { Cumulative } \\
\text { precipitation }\end{array}$} \\
\hline & & Sept & Oct & $\mathrm{N} \bullet \mathrm{v}$ & & & \\
\hline \multicolumn{8}{|l|}{ E1 Reb•llar, } \\
\hline $450 \mathrm{~m}^{*}$ & 35.36 & 40.18 & 41.96 & 90.36 & & 278.66 & 451.16 \\
\hline \multirow[t]{2}{*}{$866.6 \mathrm{~m}^{* *}$} & 94.07 & 98.92 & 112.37 & 160.77 & & 464.05 & 836.13 \\
\hline & & Sept & Oct & $\mathrm{N} \bullet \mathrm{v}$ & Dec & $\mathrm{Jan}+1$ & \\
\hline \multicolumn{8}{|c|}{ Jubaguerra stream, } \\
\hline $890 \mathrm{~m}^{*}$ & 144.52 & 96.62 & 96.95 & 223.03 & 406.61 & 638.06 & $1,461.27$ \\
\hline $866.6 \mathrm{~m}^{* *}$ & 134.52 & 92.92 & 93.65 & 212.62 & 396.2 & 627.65 & $1,423.8$ \\
\hline
\end{tabular}

* Data recounted to site of occurrence.

*** Data at the virtual-reference series; italics, data from which recurrence intervals and probabilities have been calculated.

Table III. Recurrence intervals and probabilities of occurrence for precipitation conditions associated with: (a) El Rebollar (reactivation landslide type); (b) Jubaguerra (first time failure type).

\begin{tabular}{|c|c|c|c|c|c|c|}
\hline \multirow[t]{2}{*}{ Activity } & \multicolumn{2}{|c|}{$24 \mathrm{~h}$ precipitation } & \multicolumn{2}{|c|}{ Mønthly precipitatiøn } & \multicolumn{2}{|c|}{ Cumulative precipitation } \\
\hline & $\begin{array}{l}\text { Recurrence } \\
\text { inerval } \\
\text { (in months) }\end{array}$ & $\begin{array}{l}\text { Mønthly } \\
\text { prøbability } \\
(\%)\end{array}$ & $\begin{array}{l}\text { Recurrence } \\
\text { interval } \\
\text { (in mønths) }\end{array}$ & $\begin{array}{l}\text { M॰nthly } \\
\text { prøbability } \\
(\%)\end{array}$ & $\begin{array}{l}\text { Recurrence } \\
\text { interval } \\
\text { (in years) }\end{array}$ & $\begin{array}{l}\text { Annual } \\
\text { prøbability } \\
(\%)\end{array}$ \\
\hline (El Reb•llar) & 23.77 & 4.21 & 159.57 & 0.63 & 10.44 & 9.58 \\
\hline (Jubaguerra) & 1117 & 0.09 & 1117 & 0.09 & 94 & 1.06 \\
\hline
\end{tabular}

\section{Results}

The outcomes of this analysis are:

(1) A general shallow landslide susceptibility map (Figure 5a); obtained by using a conditioning probability approach, based on the Bayes' theorem, with results that range from 0 (no probability) to 1 (maximum probability).

(2) A specific susceptibility map for shallow landslides connected to torrent channels (Figure 5b), by restricting the general susceptibility to a specific morphological pattern, obtained by applying an 'neighbourhood analysis' to the digital elevation model.

(3) A probability map of occurrence of the precipitation conditions which characterized the Jubaguerra-type phenomenon (Figure 7), obtained through statistical relationships, and later applied to the digital elevation model.

(4) A map which combines (2) and (3). This map is made by the reclassification of continued values of each of them in discrete classes (symmetric), and overlaying them while maintaining both categories (susceptibility and probability) in the legend (Figure 8). 


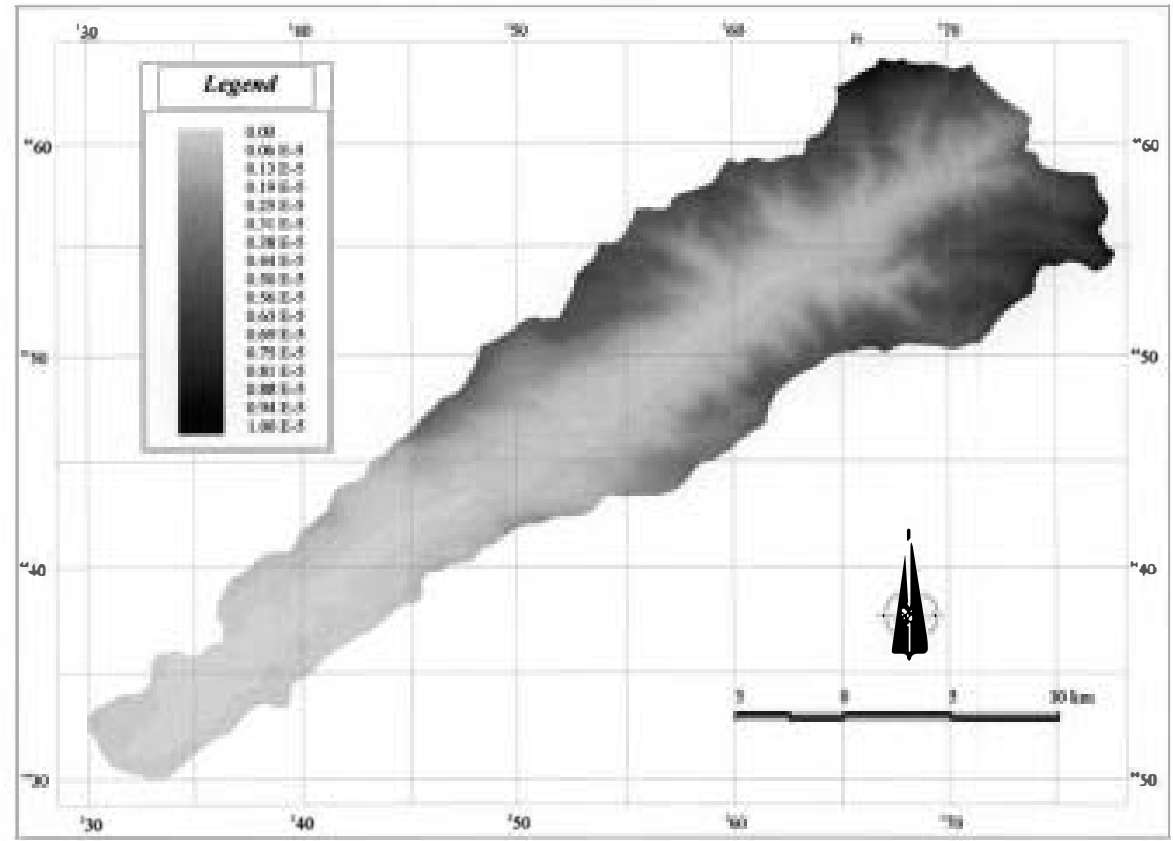

Figure 7 Conditioned digital probability map for precipitation conditions of the Jubaguerra event. In this, it is assumed that the three 'precipitation conditions' imvolved in the occurrence of the event must be met.

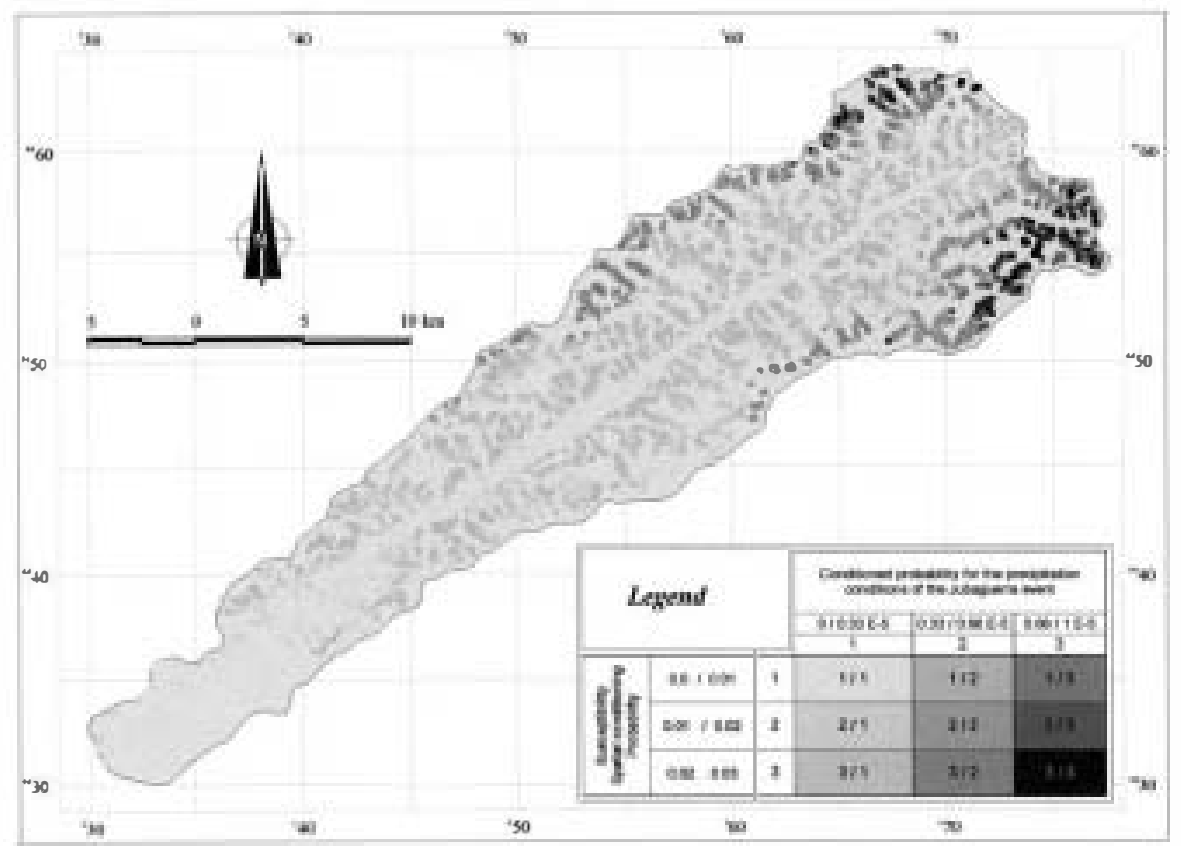

Figure \& Hazard map (or 'critical zones') due to landslides connected to fluvial processes, taking as reference the Jubaguerra-type phenomenon. 


\section{Discussion and Conclusions}

The objective of this work has been the development of a cartography for the prediction of landslides for the Jerte Valley. This cartography is shown in three maps, titled: 'general landslide susceptibility map', 'restricted susceptibility map' and 'hazard map (critical zones)'.

In order to construct the 'general landslide susceptibility map', we used all the available data from the two types of landslide activity recorded in the Valley ('first time failures' and 'reactivations'). This allowed the objective qualification and quantification of their detemining factors. Then, using GIS techniques a spatial susceptibility map was constructed.

The 'restricted susceptibility map' reflects the probability that the mass movement activity and torrential dynamics are related. The characterization of the connection between slope dynamics and torrent channels has been the basis for restricting the 'general susceptibility' in this specific situation, solved by imposing a particular geomorphic condition, obtained through the analysis of the referent process - the Jubaguerra-type phenomenon. Extracting a particular morphological pattern from the digital elevation model and carrying out a 'neighbourhood analysis', allowed us to solve the problem accurately. By overlaying the referred morphological condition, as a Boolean image, with the susceptibility map we developed the 'restricted susceptibility' for the gorge slopes. This allowed us to delineate those areas in which, besides their 'intrinsic susceptibility' to instability, the possibility of an external contribution by undercutting has been added. Furthermore, this establishes the possibility that the displaced slope material will continue its movement along stream channels, either as a debris flow or as a torrential flood.

Consequently, due to the low number of landslides with a well-documented time of occurrence and the characteristics of the available precipitation records (the data are only shown in $\mathrm{mm} / \mathrm{day}$, there are only a few rain gauges in the area, and their records are not always complete), the precipitation analysis carried out in this work can not have the establishment of 'landslide rainfall thresholds' as an end purpose. Given these restrictions, other measures had to be taken with the aim of extracting, from the available data, a first approach to the time probability of landslides in the Jerte Valley.

The procedure we followed started by assessing the precipitations regimes in the Jerte Valley; for that, we completed the existing meteorological data by using an interpolation procedure. Later, the recurrence intervals for the precipitation conditions associated with two well-documented events, the Jubaguerra and the El Rebollar landslides, were calculated. These two events are considered to represent the two typologies of the current mass movement activity within the Jerte Valley. The former represents the 'first-time failure' type (shallow slides and flows, located in gorge slopes), the latter represents the 'reactivation of domant landslides' type (cracks, minor slides, falls, etc.) affecting first generation landslides. 
Regarding the case of the 'reactivations', their characteristics make possible to carry out field monitoring of their activity by using direct methods. The landslides and their displaced materials are accurately mapped; also there are both natural and artificial indicators that allow us to record this activity (rees, fences, terraces, buildings, road cuts, etc.). In the case of the 'first- time failures', however, their field racking is much more expensive and complex, and indirect methods of prediction are necessary to accurately monitor these processes. This circumstance explains why a more complete analysis of the data supplied by the precipitation record was applied in this work to the 'first-time failure' type activity. The combining of the restricted spatial susceptibility and time probability of 'precipitation conditions' offers a first approach to the hazard zoning of a potential damaging event such as the Jubaguerra-type phenomenon (Figure 8).

According to the probability analysis of the 'precipitation conditions' (Table III), it can be concluded that the Jubaguerra event was an 'extreme phenomena. The recurrence interval for the different precipitation figures is of 94 years. However, to explain this conclusion, it must be said that:

- The Jubaguerra phenomenon was, in reality, the association of four processes: an exceptional flood in the fluvial channels, a slope undercutting, a landslide, and the resulting torrential flood. However, it is not necessary to have the concurrence of all these processes to produce similar results. Channel undercutting is not necessary to rigger shallow landslides that extend into and dam stream channels. What is necessary for the phenomena is enough precipitation in order to increase pore water pressures in soils as well as enough stream flow in the channel. The rupture of the dam and the rapid emptying of the upstream reservoir, would then lead a torrential flood down the channel.

- The interdependence of these phenomena is complex: this torrential flood was totally dependant on the landslide and the spate within the channels, whereas, these latter processes (landslide and spates) were completely independent.

- As the conditions to rigger each one of these events are not the same, it is logical to conclude that the precipitation conditions that came together in the Jubaguerra phenomenon can not be used as a 'landslide rainfall threshold'. However, they can be used as an indicator to establish the probability of occurrence of analogous events in the Jerte Valley. This conclusion is also reinforced by the fact that high intensity and short-lasting rains in mountainous areas can occur in local convective events, that do not leave their record in rain gauges (unless they are exactly located at that point). Therefore, the recurrence intervals calculated from the general precipitation conditions might not register those events. In this case, as an example, it is suitable to ref er to two torrential floods where those limitations have become evident : the Barranco de Arás flood, in the Spanish Central Pyrenees (García-Ruiz et al., 1996; White et al., 1997; Alcoverro et al., 1999), and the Arroyo del Herradón flood, over an area of the Gredos Mountains close to the Jerte Valley (Díez Herrero, 2001). 
According to these studies, the precipitation conditions of the Jubaguerra event used here present a pattern for outlining those areas with a higher probability of occurrence of 'extreme phenomena', which are shown on a map of 'critical zones' (Figure 8).

Compared to the results of the Jubaguerra event, the precipitation conditions for the El Rebollar case have a higher probability of occurrence (Table III). For this type of reactivation landslides, an important statement can be made. Different from the landslides reactivations in which there has been an artificial intervention (such as road cuts, buildings, terracing, deforestation for grazing and cherry wee cultivation, etc.), the El Rebollar case was chosen for precipitation analysis because many natural conditions (of landform and vegetation) remain. Considering that a continuous - although non periodic - activity has been recorded during the last years of the monitoring of landslide displaced materials, in which an intense anthropogenic activity has occurred, it seems logical to conclude that this situation is brought on by an artificial instability added to the 'natural' or 'nearly natural' reactivation of these mass movements.

Finally, this study indicates the convenience of using GIS and statistical analysis to delineate hazardous zones resulting from complex phenomena. In the particular case of the Jerte Valley, the rapidly expanding area of cherry tree cultivation, makes the planning of land use valuable using this type of tool.

\section{Acknowledgements}

The authors acknowledge the valuable cooperation of Andrew E. Godfrey for his critical review of the manuscript and for the improvement of its English usage, as well as the comments of two anonymous reviewers.

\section{References}

Alcoverro, J., Corominas, J., and Gómez, M.: 1999, The Barranco de Arás flood of 7 August 1996 (Biescas, Central Pyrenees, Spain), Engng. Geol. 51, 237-255.

Alexander, D. and Fornichi, R.: 1993, Tectonic causes of landslides, Earth Surface Processes and Land forms 18, 311-338.

Ayala, F. J.: 1995, Probabilidad y vulnerabilidad en movimientos de ladera, In: C. Caride (ed.), Re-

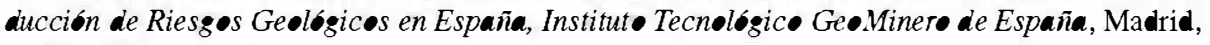
pp. 95-113.

Brabb, E. E.: 1984, Innovative approaches to landslide hazard and risk mapping, 4th International Symposium on Landslides, Toronto, 1, 307-323.

Butzer, K. V. and Fränzle, O.: 1959, Observations on Pre-Würnn glaciations of the Iberian Peninsula, Zeits. Geomorph. 3(1), 85-97.

Carrara, A., Cardinali, M., Guzzetti, F., and Reichenbach, P.: 1995, GIS technology in mapping landslides hazards, In: A. Carrara and F. Guzzetti (eds.), Geøgraphical Information Systems in Assessing Natural Hazards, Kluwer Academic Publishers, Dordrecht, Boston and London, pp. $135-175$.

Carrasco, R. M.: 1999, Geomorfoløgía del Valle del Jerte. Las líneas maestras del paisaje, Univ. de Extremadura (UEX), Cáceres, 246 pp. 
Carrasco, R. M. and Pedraza, J.: 1992, Fenómenos gravitacionales en el Valle del Jerte: tipologías y significado morfológico, In: F. López-Bennúdez et al. (eds.), Estudies de Geomørfoløgía de España, Sociedad Española de Geomorfología (SEG), Murcia, pp. 435-444.

Carrasco, R. M., Pedraza, J., Martín-Duque, J. F, Mattera, M., and Sanz, M. A.: 2000, Landslide susceptibility zoning for risk analysis using a geographical information system (GIS) in the Jerte Valley (Spanish Central System), In: C. A. Brebbia (ed.), Risk Analysis II, WIT press, Southampton-Boston, pp. 329-344.

Corominas, J.: 1988, Mapas de peligrosidad de movimientos de ladera, In: F. Ayala y J. Durán (eds),

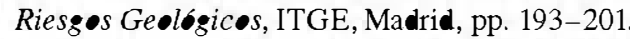

Corominas, J., Remondo, J., Farias, P. et al.: 1996, Debris flow, In: R. Dikau et al. (eds), Landslide Rec@gnition: Identification, Movement and Causes, John Wiley, Chichester, pp. 161-180.

Crozier, M. J., Deimel, M. S., and Simon, J. S.: 1995, Investigation of earthquake triggering for deep-seated landslides, Taranaki, New Zealand, Quaternary International 25, 65-73.

Diez Herrero, A :: 2001, Geomørfoløgia e Hidroløgía Fluvial del rí Alberche. Modelos y SIG para la gestión de riberas, Tesis Doctoral, Universidad Complutense, Madrid, $584 \mathrm{pp}$.

Flageollet, J. C.: 1989, Les Mouvements de Terrain et leur Prévention, Masson, Paris, 224 pp.

Flores del Manzano, F.: 1984, Hacia una Historia de la Alta Extremadura: el Valle del Jerte, Sanguino, Plasencia, $227 \mathrm{pp}$.

García Ruiz, J. M., White, S. M., Martí, C. et al:: 1996, La catástrofe del Barrance de Arás (Biescas, Pirine aragonés), y su context espaci• temporal, Instituto Pirenaico de Ecología, CSIC, Zaragoza, 54 pp.

Garland, G. G. and Olivier, M. J.: 1993, Predicting landslides from rainfall in a humid, subtropical region, Geomorph $\log y$ 8, 165-173.

Giani, G. P.: 1992, Reck Sløpe Stability Analysis, Balkema, Rotterdam, 361 pp.

Hansen, M. J.: 1984, Strategies for classification of landslides, In: D. Brunsden and D. B. Prior (eds), Slope Instability, John Wiley \& Sons Ltd., Chichester, pp. 1-25.

Irigaray, C. and Chacón, J.: 1991, Los movimientos de ladera en el sector de Colmenar, Málaga, Rev. Soc. Geol. España 4(3-4), 203-214.

IGN: 2000, Cataløg• General de Sismøs, Instituto Geográfico Nacional, Madrid.

ITGE: 1989, Mapa del Cuaternarie de España, E. 1:1.000.000, Instituto Tecnológico GeoMinero, Madrid.

Molina, E., Cantano, M., Vicente, M. A., and García, M. P.: 1990, Some aspects of paleoweathering in the Iberian Hercynian Massif, Catena 17, 333-346.

Palacios, D. and Marcos, J.: 1998, Geomorphologic hazards in a glaciated granitic massif: Sierra de Gredos, Spain, In: J. Kalvoda and C. L. Rosenfeld (eds), Geomorphølogical Hazards in High Mountain Areas, Kluwer Academic Publishers, Dordrecht, pp. 285-307.

Pierson, T. C. and Costa, J. E.: 1987, A rheologic classification of sub-aerial sediment-water flows, In: J. E. Costa and G. F. Wieczorek (eds), Debris Flows/Avalanches: Process, Recognition and Mitigation, Reviews in Engineering Geology, Vol. VII, Geological Society of America, pp. 1-12.

Sarkar, S., Kanungo, D. P., and Mehrotra, G. S.: 1995, Landslide hazard zonation; a case study in Garhwal Himalaya, India, Mountain Research and Development 15(4), 301-309.

Uromeihy, A. and Mahdavifar, M. R.: 2000, Landslide hazard zonation of the Khorshrostam area, Iran. Bull. Eng. Geol. Em. 58, 207-213.

Van Westen, C. J.: 1993, Application of Ge@raphic Information Systems to Landslide Hazard Zonation, ITC Publication 15, 245 pp.

Varnes, D. J.: 1978, Slope movement: types and processes, In: R. L. Schuster and R. J. Krizek (eds), Landslides: Analysis and Control, Transportation Research Board, National Academy of Sciences, Washington D.C. Special Report 176, Chapter 2: 11-33.

Vames, D. J. and Commission on Landslides and Other Mass-Movements on Slopes-IAEG: 1984, Landslides Hazard Zonation: A Review of Principles and Practice, Natural Hazards, 3, Unesco, Paris. 
White, S., García-Ruiz, J. M., Martí, C.: 1997, The 1996 Biescas camp site disaster in the Central Spanish Pyrenees and its temporal and spatial context, Hydrological Processes 11, 1797-1812. WP/WLI (Working Party on World Landslide Inventory): 1993, A suggested method for describing the activity of a landslide, Bull. I.A.E.G. 47, 53-57. 